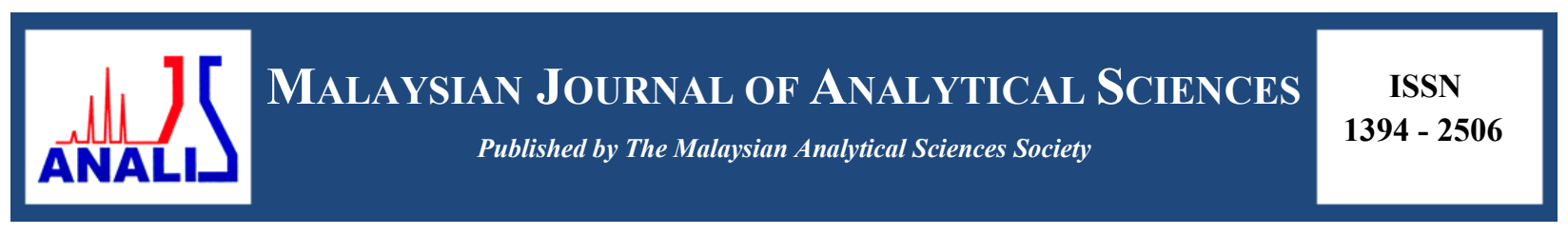

\title{
CHARCOAL BASE METALLIC COMPOSITE ELECTRODE FOR WASTEWATER TREATMENT
}

\section{(Elektrod Komposit Logam Berasaskan Arang Bagi Rawatan Air Buangan)}

\author{
Majd Ahmed Jumaah ${ }^{1 *}$, Mohamed Rozali Othman ${ }^{1,2}$, Muhammad Rahimi Yusop ${ }^{1}$, Jumat Salimon ${ }^{1}$, \\ Baydaa Khalaf ${ }^{1}$, Wan Mohd Afiq Wan Mohd Khalik ${ }^{3}$ \\ ${ }^{I}$ School of Chemical Sciences and Food Technology \\ ${ }^{2}$ Centre for Water Research and Analysis (ALIR) \\ Faculty of Science and Technology, \\ Universiti Kebangsaan Malaysia, 43600 UKM Bangi, Selangor, Malaysia \\ ${ }^{3}$ School of Marine and Environmental Sciences, \\ Universiti Malaysia Terengganu, 21030 Kuala Nerus, Terengganu, Malaysia \\ *Corresponding author: majd.ahmed88@yahoo.com
}

Received: 28 September 2016; Accepted: 6 March 2017

\begin{abstract}
In this study, a charcoal base metallic composite electrode which is low in cost and effective to treat wastewater from landfill leachate by electrochemical oxidation technique has been fabricated. The charcoal base metallic composite electrode was prepared by mixing together a weighed portion of charcoal, graphite and metals powder in different composition percentage with PVC as a binder in $4 \mathrm{~mL}$ THF which act as a solvent. Metals used in the preparation of the electrodes are $\mathrm{Ag}, \mathrm{Al}, \mathrm{Co}, \mathrm{Cu}$ and $\mathrm{Ni}$. The results show that the mixture of commercially available charcoal, metals and PVC at a composition of 50:20:30 (w/w), known as C50M20PVC30 electrode give a good stability, low cost and high formation of hypochlorite ion. Hypochlorite ion has been produced linked to the presence of chloride ions, thus having capability to degrade chemical pollutants in wastewater.
\end{abstract}

Keywords: charcoal, electrode, treatment, wastewater

\section{Abstrak}

Dalam kajian ini, elektrod komposit logam berasaskan arang dengan kos rendah dan efektif dalam merawat air buangan daripada tanah larut resap melalui teknik pengoksidaan elektrokimia telah dibangunkan. Elektrod komposit logam berasaskan arang telah disediakan dengan mencampurkan arang, grafit dan serbuk logam pada peratus komposisi yang berbeza di mana polivinil klorida sebagai pengikat di dalam $4 \mathrm{~mL}$ tetrahidrofuran (THF) sebagai pelarut. Logam yang digunakan dalam penyediaan elektrod ialah $\mathrm{Ag}, \mathrm{Al}, \mathrm{Co}, \mathrm{Cu}$ dan Ni. Keputusan menunjukkan campuran arang komersial, logam dan PVC pada nisbah 50:20:30 (w/w), yang dikenali sebagai elektrod C50M20PVC30 memberi kestabilan yang baik, berkos rendah dan menghasilkan ion hipoklorit yang tinggi. Semasa pengoksidaan elektrokimia, ion hipoklorit telah dihasilkan disebabkan oleh kehadiran ion klorida yang membawa kepada keupayaan untuk penyingkiran bahan pencemar kimia di dalam air buangan.

Kata kunci: arang, elektrod, rawatan, air buangan

\section{Introduction}

Water purification is one of the most pervasive problems affecting people throughout the world [1]. Various methods of wastewater treatment have been reported and this process is divided into three, namely chemical, physical and biological [2]. Up to now, electrochemical oxidation process has been proved to be promising for 
wastewater treatment mainly due to its high effectiveness, easy to operate and more economic $[3,4]$. In the case of landfill leachate, it was known having high concentration chloride ions and good conductivity. Many researchers have investigated the effectiveness of electrochemical oxidation process toward various types of wastewater including leachate wastewater $[5,6]$. Leachate also known having high chemical oxygen demand (COD), high levels of ammonia and phosphorus as well as total dissolved solid content (TDS) [7]. To reach environmental friendly criteria for landfill leachate, chemical pollution should be minimized to an acceptable discharge limit [8].

Therefore, the aim of this study is to evaluate the effectiveness of charcoal base metallic composite electrode for color removal during electrochemical oxidation process. Characterization of prepared charcoal base metallic composite electrodes also has been studied.

\section{Preparation of electrodes}

\section{Materials and Methods}

Composite electrodes based on ratio composition of charcoal-metals-PVC were prepared. A weighed portion of charcoal powder, metals with PVC in $4 \mathrm{~mL}$ tetrahydrofuran (THF) solvent was mixed together and swirled flatly to homogeneous, followed by drying in an oven at temperature set $100^{\circ} \mathrm{C}$ for 3 hours. The mixture was then placed in $1 \mathrm{~cm}$ diameter stainless steel mould and pressed at 10 ton/cm [9]. The pellets were connected to silver wire with epoxy gum and coated silver conducting paint.

\section{Experimental procedures}

All experiments were carried out at ambient temperature. The lab scale electrochemical cell was designed by using DC set power supply, glass reactor and magnetic stirrer. Leachate sample $(50 \mathrm{~mL})$ was then added into cell with known concentration supporting electrolyte. Sample in the electrochemical cell was kept stirred at $300 \mathrm{rpm}$ for homogenise condition. The effect of $\mathrm{pH}$ was studied by adjusting leachate sample using $\mathrm{HCl}$ or $\mathrm{NaOH}$ solution. The effect of sodium chloride concentration as the supporting electrolyte also was carried out. Electrochemical reaction was started once the specified voltage was introduced into the system. Leachate samples were treated at different time and different operating parameters. The removal efficiency $(\% \mathrm{R})$ of color sample during electrochemical oxidation process was calculated using following equation 1 [10].

$$
\% R=\frac{\left[100\left(R_{0}-R_{t}\right)\right]}{R_{0}}
$$

where $\% \mathrm{R}$ is the removal percentage for color, $\mathrm{R}_{0}$ is initial value of color, $\mathrm{R}_{\mathrm{t}}$ is the value color at time $t$.

\section{Sampling}

Leachate samples were collected from Jeram Sanitary Landfill, situated in oil palm plantation near Mukim Jeram, Kuala Selangor. Leachate samples were transported to chemical laboratory and stored in a refrigerator at $4^{\circ} \mathrm{C}$ prior analysis.

\section{The stability of electrode}

\section{Results and Discussion}

Different compositions of commercially available charcoal powder base metallic composite electrode with PVC were prepared. Different types of metals such as silver, aluminum, cobalt, copper and nickel were used as metal based. All electrodes hardness was tested to determine whether composition of charcoal and metal powders having high stability to use it during electrochemical treatment process. Table 1 depicted the stability of charcoal base metallic composite electrode.

Finding study shows ten composition of electrodes having good stability which can be used in electrochemical treatment process. The stability of composite electrode was improved once the percentage of PVC was increased. The characterization explains that PVC acts as a binder, filled the porosity of charcoal and increase resistivity of electrode $[10,11]$. Nonetheless, the amount of PVC was kept as low as possible, to avoid reducing surface area or conductivity of composite electrode during this study. 
Table 1. The stability of commercially available charcoal powder base metallic composite electrode

\begin{tabular}{cccl}
\hline \multicolumn{3}{c}{ Percentage $\%(w / w)$} & Electrode \\
Charcoal & PVC & Metal Powder & Stability \\
\hline 10 & 10 & 80 & Hard \\
20 & 10 & 70 & Hard \\
30 & 15 & 60 & Hard \\
40 & 15 & 45 & Hard \\
50 & 20 & 30 & Hard \\
60 & 30 & 10 & Hard \\
70 & 20 & 10 & Hard \\
80 & 10 & 10 & Crumble \\
85 & 10 & 5 & Crumble \\
90 & 5 & 5 & Crumble \\
95 & 5 & - & Crumble \\
90 & 10 & - & Crumble \\
85 & 15 & - & Breakable \\
80 & 20 & - & Breakable \\
75 & 25 & - & Breakable \\
70 & 30 & - & Hard \\
60 & 40 & - & Hard \\
50 & 50 & - & Hard \\
\hline
\end{tabular}

Note: stability of electrode $=$ The hardness of pellet after preparation

\section{Optimization of anode material composition}

Electrode based materials was known having influence toward the efficiency of electrochemical process include for wastewater treatment $[12,13]$. Good composite electrode was evaluated based on the efficiency of color removal in leachate samples. The operating condition: applied voltage $(10 \mathrm{~V})$ and $\mathrm{NaCl}$ concentration $(1.5 \% \mathrm{w} / \mathrm{v})$ was remain constant during treatment process. Expenses costs of all composite electrodes used in this study were calculated based on manufacturer prices (Sigma-Aldrich, USA). The results obtained is summarised as in Table 2.

Table 2. Electrochemical oxidation of landfill leachate under different operating condition

\begin{tabular}{|c|c|c|c|c|c|c|}
\hline \multirow[t]{2}{*}{ Electrode } & \multirow{2}{*}{$\begin{array}{c}\text { Electrolysis } \\
\text { Time } \\
\text { (min) }\end{array}$} & \multirow{2}{*}{$\begin{array}{c}\text { Color } \\
\text { Removal } \\
(\%)\end{array}$} & \multicolumn{2}{|c|}{ Observation } & \multirow{2}{*}{$\begin{array}{l}\text { Cost } \\
\text { USD }\end{array}$} & \multirow{2}{*}{$\begin{array}{c}\mathrm{ClO}^{-} \\
\text {Production } \\
\text { (Abs) }\end{array}$} \\
\hline & & & $\begin{array}{l}\text { Electrolysis } \\
\text { Product }\end{array}$ & Anode & & \\
\hline C50Ag20PVC30 & 360 & 61 & $\begin{array}{l}\text { Yellowish } \\
\text { Solution }\end{array}$ & Slightly corroded & 1.13 & 3.9 \\
\hline С50Co20PVC 30 & 120 & 58 & $\begin{array}{l}\text { Yellowish } \\
\text { Solution }\end{array}$ & Unchanged & 0.30 & 1.2 \\
\hline $\mathrm{C} 50 \mathrm{Cu} 20 \mathrm{PVC} 30$ & 180 & 44 & $\begin{array}{l}\text { Yellowish } \\
\text { Solution }\end{array}$ & $\begin{array}{l}\text { Completely } \\
\text { corroded }\end{array}$ & 1 & - \\
\hline C50A120PVC30 & 300 & 23 & $\begin{array}{l}\text { Yellowish } \\
\text { Solution }\end{array}$ & Unchanged & 0.15 & 0.3 \\
\hline
\end{tabular}


Table 2 (cont'd). Electrochemical oxidation of landfill leachate under different operating condition

\begin{tabular}{|c|c|c|c|c|c|c|}
\hline \multirow[t]{2}{*}{ Electrode } & \multirow{2}{*}{$\begin{array}{c}\text { Electrolysis } \\
\text { Time } \\
\text { (min) }\end{array}$} & \multirow{2}{*}{$\begin{array}{c}\text { Color } \\
\text { Removal } \\
(\%)\end{array}$} & \multicolumn{2}{|c|}{ Observation } & \multirow{2}{*}{$\begin{array}{l}\text { Cost } \\
\text { USD }\end{array}$} & \multirow{2}{*}{$\begin{array}{c}\mathrm{ClO}^{-} \\
\text {Production } \\
\text { (Abs) }\end{array}$} \\
\hline & & & $\begin{array}{l}\text { Electrolysis } \\
\text { Product }\end{array}$ & Anode & & \\
\hline C50Ni20PVC30 & 360 & 4 & $\begin{array}{l}\text { Color } \\
\text { unchanged }\end{array}$ & $\begin{array}{l}\text { Completely } \\
\text { corroded }\end{array}$ & 0.97 & - \\
\hline C60Ag10PVC30 & 180 & 33 & $\begin{array}{l}\text { Yellowish } \\
\text { Solution }\end{array}$ & Slightly corroded & 0.63 & 1 \\
\hline C60Co10PVC30 & 120 & 29 & $\begin{array}{l}\text { Yellowish } \\
\text { Solution }\end{array}$ & Unchanged & 0.20 & 0.7 \\
\hline C60Cu10PVC30 & 180 & 22 & $\begin{array}{l}\text { Yellowish } \\
\text { Solution }\end{array}$ & $\begin{array}{l}\text { Completely } \\
\text { corroded }\end{array}$ & 0.86 & - \\
\hline C60A110PVC30 & 180 & 7 & $\begin{array}{l}\text { Color } \\
\text { unchanged }\end{array}$ & Unchanged & 0.13 & 0.08 \\
\hline C60Ni10PVC30 & 180 & 5 & $\begin{array}{l}\text { Color } \\
\text { unchanged }\end{array}$ & $\begin{array}{l}\text { Completely } \\
\text { corroded }\end{array}$ & 0.71 & - \\
\hline C70Ag10PVC20 & 180 & 32 & $\begin{array}{l}\text { Yellowish } \\
\text { Solution }\end{array}$ & Slightly corroded & 0.60 & 0.9 \\
\hline C70Co10PVC20 & 240 & 32 & $\begin{array}{l}\text { Yellowish } \\
\text { Solution }\end{array}$ & Unchanged & 0.19 & 0.4 \\
\hline $\mathrm{C} 70 \mathrm{Cu} 10 \mathrm{PVC} 20$ & 180 & 28 & $\begin{array}{l}\text { Yellowish } \\
\text { Solution }\end{array}$ & $\begin{array}{l}\text { Completely } \\
\text { corroded }\end{array}$ & 0.81 & - \\
\hline C70A110PVC20 & 180 & 9 & $\begin{array}{l}\text { Color } \\
\text { unchanged }\end{array}$ & Unchanged & 0.11 & 0.05 \\
\hline C70Ni10PVC20 & 240 & 6 & $\begin{array}{l}\text { Color } \\
\text { unchanged }\end{array}$ & $\begin{array}{l}\text { Completely } \\
\text { corroded }\end{array}$ & 0.67 & - \\
\hline
\end{tabular}

Note: $\mathrm{OCl}^{-}=$the formation of hypochlorite ion in $50 \mathrm{~mL}$ deionized water, $1.5 \%(\mathrm{w} / \mathrm{v}) \mathrm{NaCl}$ and 30 minutes electrolysis time for only the stable electrodes.

Finding study shown that the best composite electrode (C50Co20PVC30) gave 58\% of color removal without any changes on physical properties. Although C50Ag20PVC30 composite electrode record color removal till $61 \%$ but the stability of electrode is low and the cost to fabricate the electrode was higher. As the main criteria electrode used in any electrochemical process should be stable chemically and physically $[14,15]$. Therefore, the selection of good composite electrode is not only based on the ability to remove the color, but chemical stability as well. The composition of C50Co20PVC30 was identified as best composite, then it was used in the next experiment.

In further experiment, formation of hypochlorite ion has been investigated by adding $1.5 \%(\mathrm{w} / \mathrm{v}) \mathrm{NaCl}$ solution to $50 \mathrm{~mL}$ of deionized water in electrochemical cell. During treatment process, hypochlorite ions production was linked to presence of chloride ions. It was believed that the presence of hypochlorite ions able to degrade chemical pollutants in leachate samples [16]. The formation of hypochlorite ion in aqueous solution was determined using UV-visible spectrophotometer. Comparison of four characteristics (color, cost, hypochlorite ion formation and electrode stability) to determine the best composite electrode is shown in Figure 1. 


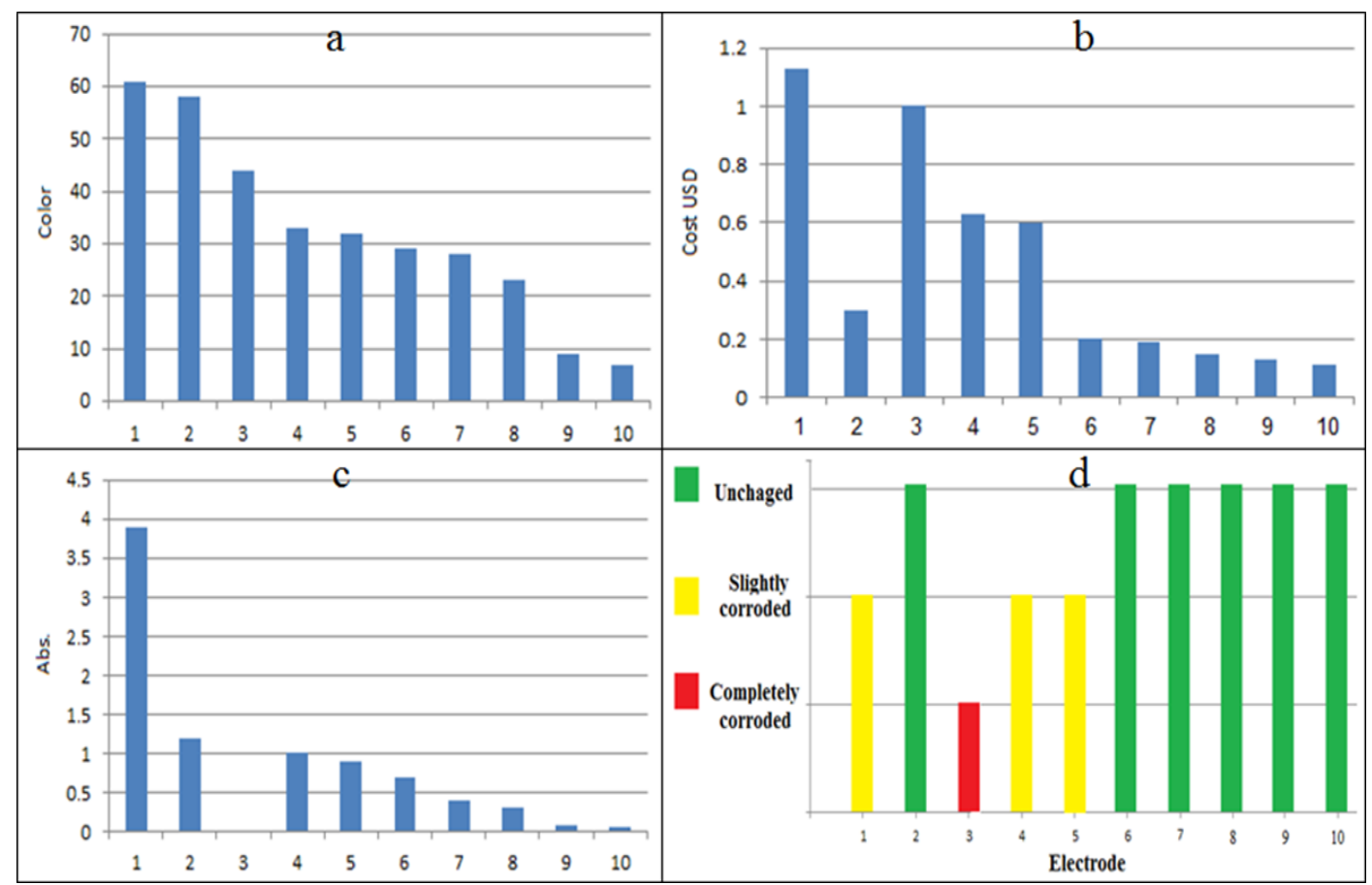

Note: 1. C50Ag20PVC30, 2. C50Co20PVC30, 3. C60Ag10PVC30, 4. C70Ag10PVC30, 5. C70Ag10PVC20, 6. C60Co10PVC30, 7. C70Co10PVC30, 8. C50Al20PVC30, 9. C60Al10PVC30 and 10. C70Al10PVC20

Figure 1. Comparison of different composite electrode in term of a) color removal, b) electrode cost in USD, c) hypochlorite ion formation in deionize water and d) electrode stability

\section{Conclusion}

The present study successfully proves the most suitable charcoal base metallic composite electrode is C50Co20PVC30 as anode in electrochemical oxidation process for the treatment of landfill leachate. It was successfully performed for color removal and good stability. The color removal efficiency (58\%) linked to increase the presence of hypochlorite ion, then lead the degradation of organics present in the effluent.

\section{Acknowledgement}

This work was supported by the National University of Malaysia and Ministry of Higher Education, Malaysia through grants number FRGS/2/2013/SG01/UKM/01/1 are gratefully acknowledged.

\section{References}

1. Noruzman, H. A., Ismail, M. B. and Abdul-Majid, Z. (2012). Characteristics of treated effluents and their potential applications for producing concrete. Journal of Environmental Management, 15: 27 - 32.

2. Jumaah, M. A., Othman, M. R. and Yusop, M. R. (2016). Batch method treatment of landfill leachate using charcoal composite. International Journal of Chem Tech Research, 9: 583 - 586.

3. Pérez-González, A., Urtiaga, A. M., Ibáñez, R. and Ortiz, I. (2012). State of the art and review on the treatment technologies of water reverse osmosis concentrates. Water Research, 46(2): $267-283$.

4. Martinez-Huitle, C. A. and Ferro, S. (2006). Electrochemical oxidation of organic pollutants for the wastewater treatment: Direct and indirect processes. Chemical Society Reviews 35: $1324-1340$.

5. Deng, Y. and James, D. E. (2007). Electrochemical oxidation for landfill leachate treatment. Waste Management, 27: 380 - 388 . 
6. Mook, W. T., Chakrabarti, M. H., Aroua, M. K., Khan, G. M. A., Ali, B. S., Islam, M. S. and Hassan, M. A. (2012). Removal of total ammonia nitrogen (TAN), nitrate and total organic carbon (TOC) from aquaculture wastewater using electrochemical technology: A review. Desalination, 285: 1- 13.

7. Jumaah, M. A., Othman, M. R. and Yusop, M. R. (2016). Characterization of leachate from Jeram Sanitary Landfill-Malaysia. International Journal of ChemTech Research, 9: 571 - 574.

8. MoayeriKashani, M., Soltani, S. M. and Sobri, S. (2012). Treatment of a Malaysian leachate sample using electrocoagulation. International Journal of Chemical Engineering and Applications, 3(1): 63 - 66.

9. Zakaria, Z., Nordin, N., Hasan, S. Z., Baharuddin, N. F., Jumaah, M. A. and Othman, M. R. (2015). Decolorization of reactive orange 16 dye using fabricated charcoal base metallic composite electrode. Malaysian Journal of Analytical Sciences, 19: 493 - 502.

10. Jumaah, M. A., Othman, M. R. and Zakaria, Z. (2015). Fabrication of selected metal powder composite electrode for landfill leachate treatment using electrochemical method. International Journal of Chemical Sciences 13: $943-954$.

11. Ruiz, V., Blanco, C., Granda, M., Menéndez, R. and Santamaría, R. (2007). Influence of electrode preparation on the electrochemical behaviour of carbon-based supercapacitors. Journal of Applied Electrochemistry, 6: $717-721$.

12. Jumaah, M. A. and Othman, M. R. (2015). Study the efficiency of various metal powder composition electrodes based on landfill leachate treatment. International Journal of ChemTech Research, 8: 559 -563.

13. Jumaah, M. A. and Othman, M. R. (2015). Optimization of operating conditions for landfill leachate treatment using electrochemical oxidation technique. International Journal of ChemTech Research 8: 783 - 787.

14. Jumaah, M. A. and Othman, M. R. (2015). COD removal from landfill leachate by electrochemical method using charcoal-PVC electrode. International Journal of ChemTech Research 8: 604 - 609.

15. Nordin, N., Amir, S. F. M., Yusop, M. R. and Othman, M. R. (2015). Decolorization of CI reactive orange 4 and textile effluents by electrochemical oxidation technique using silver-carbon composite electrode. Acta Chimica Slovenica, 62: $642-651$.

16. Jumaah, M. A. and Othman, M. R. (2015). Optimization of electrochemical parameters for landfill leachate treatment using charcoal base metallic composite electrode. Malaysian Journal of Analytical Sciences, 19: $531-540$.

17. Othman, M. R. and Riyanto (2012). Electrochemical stability of $\mathrm{Cu}, \mathrm{Ni}, \mathrm{Co}, \mathrm{Pt}$ and $\mathrm{Ir}$ metals sheet and their composite electrodes in potassium hydrox de solution. International Journal of Electrochemical Science, 7: $8408-8419$.

18. Jumaah, M. A., Othman, M. R. and Yusop, M. R. (2016). Electrochemical treatment of landfill leachate: Optimization of COD removal using charcoal- graphite- cobalt- polyvinyl chloride electrode. Research Journal of Pharmaceutical, Biological and Chemical Science, 7: 2812 - 2816. 